\title{
Potential Risk Factors Associated with Infection with Bovine Leukaemia Virus in Dairy and Beef Cattle in Taiwan
}

\author{
Yi-Chen Chen ${ }^{1,+}$, Wen-Yu Chin ${ }^{2,+}$, Chao-Chin Chang ${ }^{3}$, Shih-Te Chuang ${ }^{4}$ and Wei-Li Hsu ${ }^{3, *(D)}$ \\ 1 Division of Endocrinology and Metabolism, Department of Internal Medicine, Taichung Veterans General \\ Hospital, Taichung 407, Taiwan; tyler7418@hotmail.com \\ 2 Department of Farm Animal Health, Faculty of Veterinary Medicine, Utrecht University, 3584 CS Utrecht, \\ The Netherlands; kellywychin@gmail.com \\ 3 Graduate Institute of Microbiology and Public Health, College of Veterinary Medicine, National Chung Hsing \\ University, Taichung 402, Taiwan; changcc@dragon.nchu.edu.tw \\ 4 Department of Veterinary Medicine, College of Veterinary Medicine, National Chung Hsing University, \\ Taichung 402, Taiwan; stchuang@dragon.nchu.edu.tw \\ * Correspondence: wlhsu@dragon.nchu.edu.tw; Tel.: +886-4-22840695 \\ + These two authors had equal contribution to this study.
}

Citation: Chen, Y.-C.; Chin, W.-Y.; Chang, C.-C.; Chuang, S.-T.; Hsu, W.-L. Potential Risk Factors

Associated with Infection with Bovine Leukaemia Virus in Dairy and Beef Cattle in Taiwan. Pathogens 2021, 10, 1553. https://doi.org/10.3390/ pathogens 10121553

Academic Editors: Paul C. Bartlett and Lawrence S. Young

Received: 22 September 2021

Accepted: 26 November 2021

Published: 29 November 2021

Publisher's Note: MDPI stays neutral with regard to jurisdictional claims in published maps and institutional affiliations.

Copyright: (c) 2021 by the authors. Licensee MDPI, Basel, Switzerland. This article is an open access article distributed under the terms and conditions of the Creative Commons Attribution (CC BY) license (https:/ / creativecommons.org/licenses/by/ $4.0 /)$.

\begin{abstract}
Bovine leukaemia virus (BLV), which is classified as a Deltaretrovirus, is the aetiologic agent of enzootic bovine leukosis (EBL), a chronic lymphoproliferative disorder with a worldwide distribution. EBL is widespread in dairy herds and causes a direct economic impact due to reduced milk production and the early culling of BLV-infected cattle. The BLV infection status in Taiwan remains largely unknown; a high prevalence of BLV in dairy cows was recently revealed. The present study further investigated BLV infections in beef cattle. Surprisingly, the prevalence of BLV proviral DNA was as low as $11.8 \%(23 / 195)$, which is significantly lower than that noted in dairy cows, which was $42.5 \%(102 / 240)(p<0.001)$. Factors associated with BLV infections were subsequently investigated. Due to the differences in herd management, an analysis of risk factors for a BLV infection was independently conducted in these two sectors. Several factors associated with a BLV infection were identified. Age was significantly associated with BLV infection status in dairy cows $(p<0.001)$ but not in beef cattle. A high prevalence of BLV was observed in cattle $>15.5$ months old $(57.8 \%)$ compared with those $\leq 15.5$ months old (11.4\%). Moreover, after stratification analysis, based on the critical age of 15.5 months, as determined by the receiver operating characteristic (ROC) curve, a significantly higher BLV prevalence was demonstrated in lactating dairy cows, cattle undergoing bull breeding, heifers at older ages, and those undergoing routine rectal palpation. Due to the high prevalence of BLV in Taiwan, the development of an effective control program, based on the identified risk factors, is important for interrupting the routes of BLV transmission within herds.
\end{abstract}

Keywords: bovine leukaemia virus; dairy cows; beef cattle; heifer; risk factors

\section{Introduction}

Bovine leukaemia virus (BLV), belonging to the Deltaretrovirus genus of the Retroviridae family, is the causative agent of enzootic bovine leukosis and is the most common neoplastic disease of cattle. BLV infection is mostly asymptomatic, but in less than $5 \%$ of infected cattle, it manifests as a malignant B-cell lymphoma [1]. Additionally, a negative association has been reported between herd-level milk production and herd BLV prevalence in Canadian dairy herds [2,3]. Moreover, BLV infection has a negative impact on cow longevity $[4,5]$ and restricts the international trade of infected animals. In addition to affecting cattle, reports from Buehring and colleagues indicate the potential public health implications of BLV in humans, as evidenced by the presence of the BLV antibody (capsid antigen, p24) in 74\% of the sera [6], and proviral DNA in $44 \%$ of breast tissue [7]. However, whether BLV may play a direct role in human diseases requires further investigation. 
BLV is widespread in domestic cattle worldwide, and a high prevalence of BLV infection has been reported in many countries, including the US, Canada, Japan, and China, that lack BLV-specific eradication programs [8-11]. It is reported that horizontal transmission, including direct contact and indirect (iatrogenic) contact with blood or, less likely, with milk from BLV-affected animals, is the common mode for spreading BLV to susceptible individuals in cattle populations [12]. In particular, BLV is possibly spread by iatrogenic transmission via the use of blood-contaminated needles, instruments, or gloves in medical management, dehorning, or rectal palpation, respectively. Moreover, vertical transmission, such as the transplacental route, of BLV could also be possible $[13,14]$. Nevertheless, the contribution of the aforementioned modes of transmission could depend on the frequency and nature of BLV exposure and needs to consider the prevalence of BLV within the herds [15]. Given that BLV infection is life-long, and that persistent infection leads to a continuous detrimental effect $[16,17]$, it is necessary to determine the modes of transmission for the control of BLV infection so as to properly intervene.

Very recently, a nationwide surveillance of BLV in dairy cows was conducted in Taiwan, and the seroprevalence of BLV at the animal and herd levels was as high as $81.8 \%$ and $99.1 \%$, respectively [18]. However, the infection status in beef remains unknown. Notably, a national control program for BLV infection in dairy cows has not yet been implemented in Taiwan, potentially because of the lack of risk factor analyses for BLV infection. Hence, the main objective of this study was to identify the potential risk factors associated with cow-level BLV infection in cattle in Taiwan. In this study, the infection status in beef cattle was investigated for the first time, and the risk factors for beef and dairy cows were comparatively analysed.

\section{Results}

\subsection{Prevalence and Genotype of BLV Env Proviral DNA in Beef and Dairy Cows}

Given that BLV prevalence in beef cattle in Taiwan remains unknown, the BLV infection status in beef cattle was initially investigated by nested PCR. Of the 195 blood samples, the prevalence of BLV proviral DNA in beef was 11.8\% (23/195). Moreover, a sequence analysis of the partial env gene, amplified from beef cattle, indicated that all samples analysed were BLV genotype 1.

Notably, the BLV prevalence in beef cattle $(11.8 \%)$ was significantly lower than that in dairy cows $(42.5 \% ; 102 / 240)(p<0.001)$. It has been demonstrated that the incidence of BLV in beef and dairy cows increases with age [19]. However, no significant difference in the mean age of beef cattle infected with BLV compared with beef cattle without BLV infections was noted (Figure 1, $17.07 \pm 3.49$ vs. $19.08 \pm 1.41$ months old, respectively, $p=0.871)$. Nonetheless, the mean age of dairy cows with a BLV infection was significantly older than that of BLV-negative dairy cows (Figure 1, $38.28 \pm 1.99$ vs. $23.20 \pm 1.80$ months old, respectively, $p<0.001)$.

\subsection{Distributions of BLV Proviral DNA Prevalence among the Farm Features of Beef and Dairy Cows}

The prevalence of BLV infection in all cows enrolled in this study was further analysed based on the characteristics of farm animals. As listed in Table 1, in addition to older age, positive BLV detection occurred more often in dairy cows $(p<0.001)$, Holstein breeds $(p=0.001)$, female cattle $(p<0.001)$, herds over 400 head $(p=0.015)$, intensive management (free-stall housing) $(p=0.004)$, farm $6(p=0.015)$, cattle breeding via artificial insemination $(p<0.001)$, cattle with rectal palpation $(p<0.001)$, and cattle that were fed sterilized colostrum $(p=0.008)$. 


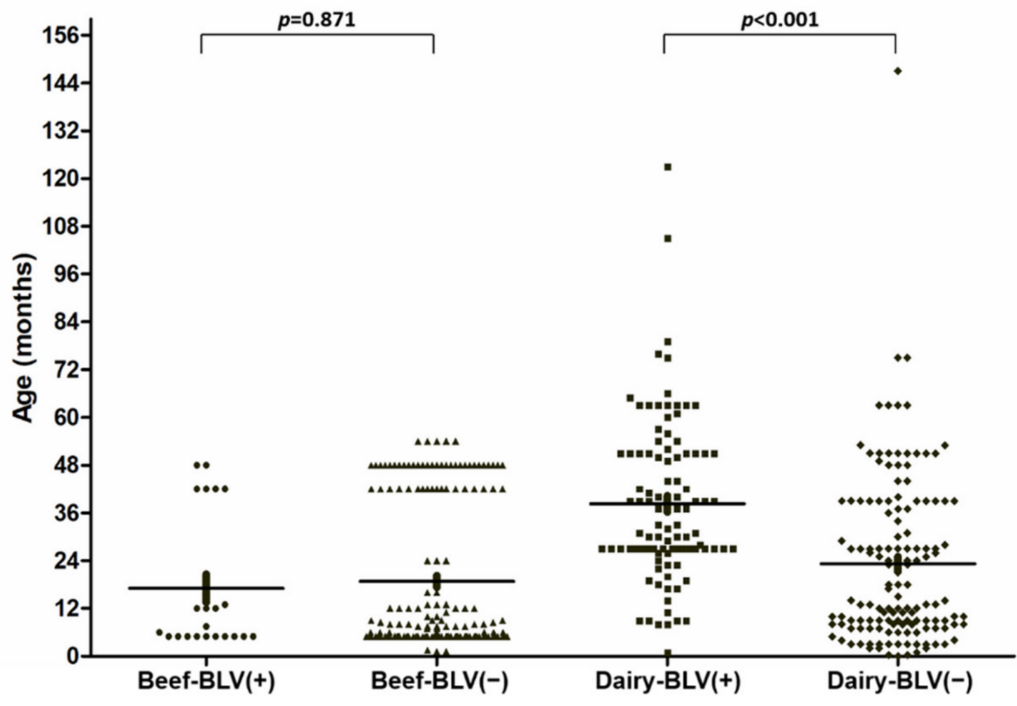

Figure 1. Distribution of ages in beef $(\boldsymbol{\bullet}$ and $\mathbf{\Delta})$ and dairy cows $(\boldsymbol{\square}$ and $\boldsymbol{\nabla})$. The age composition in the group of beef or dairy cows infected with BLV (+) or without BLV (-) were plotted.

Table 1. Univariate analysis of the association of farm features with BLV infection of all cattle.

\begin{tabular}{|c|c|c|c|}
\hline \multirow{2}{*}{ Factors } & \multicolumn{3}{|c|}{ BLV Detection } \\
\hline & Positive $(n=125)$ & Negative $(n=310)$ & $p$-Value \\
\hline \multicolumn{4}{|c|}{ Purpose of production } \\
\hline Beef & 23 & 172 & \multirow{2}{*}{$<0.001 \S$} \\
\hline Dairy & 102 & 138 & \\
\hline Age (months) & $34.38 \pm 1.90^{\dagger}$ & $20.78 \pm 1.13^{\dagger}$ & $<0.001 \ddagger$ \\
\hline \multicolumn{4}{|l|}{ Breed } \\
\hline Holstein & 118 & 249 & \multirow{3}{*}{$0.001 \S$} \\
\hline Angus & 6 & 55 & \\
\hline Mixed & 1 & 6 & \\
\hline \multicolumn{4}{|l|}{ Gender } \\
\hline Male & 13 & 97 & \multirow{3}{*}{$<0.001 \S$} \\
\hline Female & 109 & 199 & \\
\hline Castrated male & 3 & 14 & \\
\hline \multicolumn{4}{|l|}{ Herd size (head) } \\
\hline$<50$ & 19 & 47 & \multirow{4}{*}{$0.015 \S$} \\
\hline $50-200$ & 5 & 45 & \\
\hline $201-400$ & 97 & 205 & \\
\hline$>400$ & 4 & 13 & \\
\hline \multicolumn{4}{|c|}{ Management pattern } \\
\hline Intensive & 123 & 281 & \multirow{2}{*}{$0.004^{\text {II }}$} \\
\hline Pasture & 2 & 29 & \\
\hline \multicolumn{4}{|l|}{ Farm owner } \\
\hline 1 & 4 & 13 & \multirow{6}{*}{$0.015^{\S}$} \\
\hline 2 & 2 & 29 & \\
\hline 3 & 34 & 70 & \\
\hline 4 & 27 & 89 & \\
\hline 5 & 18 & 42 & \\
\hline 6 & 40 & 67 & \\
\hline
\end{tabular}


Table 1. Cont.

\begin{tabular}{|c|c|c|c|}
\hline \multirow{2}{*}{ Factors } & \multicolumn{3}{|c|}{ BLV Detection } \\
\hline & Positive $(n=125)$ & Negative $(n=310)$ & $p$-Value \\
\hline \multicolumn{4}{|l|}{ Artificial insemination } \\
\hline No & 20 & 139 & \multirow{4}{*}{$<0.001 \S$} \\
\hline No (Bull only) & 28 & 58 & \\
\hline Yes & 63 & 100 & \\
\hline Yes (Combined) & 14 & 13 & \\
\hline \multicolumn{4}{|l|}{ Regular rectal palpation } \\
\hline No & 29 & 196 & \multirow{2}{*}{$<0.001^{\S}$} \\
\hline Yes & 96 & 114 & \\
\hline \multicolumn{4}{|l|}{ Sterilized colostrum } \\
\hline No & 6 & 42 & \multirow{2}{*}{$0.008 \S$} \\
\hline Yes & 119 & 268 & \\
\hline \multicolumn{4}{|l|}{ Vaccination } \\
\hline No & 17 & 43 & \multirow{3}{*}{$0.865 \S$} \\
\hline Yes (Needle sharing) & 66 & 171 & \\
\hline Yes (One shot per needle) & 42 & 96 & \\
\hline
\end{tabular}

${ }^{\dagger}$ The values represent means \pm SEM. Differences of analytes within groups and BLV positivity was performed with the ${ }^{\ddagger}$ Mann-Whitney

$\mathrm{U}$ test, ${ }^{\mathbb{I}}$ Fisher's exact test, and ${ }^{\S}$ Chi-square test. BLV, bovine leukaemia virus. $p<0.05$ indicates significant difference.

Considering the differences in herd management, the cattle were stratified into beef and dairy cows to investigate the potential risk factors associated with BLV infection (Table 2). Interestingly, none of the farm factors significantly correlated with BLV status in beef cattle. However, in dairy cows, BLV prevalence was significantly associated with farm size $(p=0.003)$, breeding technique $(p<0.001)$, and cattle undergoing routine rectal palpations $(p<0.001)$

To evaluate the potential confounding effect due to age, the dairy cows were stratified into two groups using the age of 15.5 months as a cut-off, based on ROC curve analysis (Figure 2). As summarized in Table 3, lactating cows accounted for 96.3\% (155/161) of dairy cows older than 15.5 months, which is the optimum age for breeding in reproductive management, and almost all the dairy cows that were $\leq 15.5$ months were heifers $(98.7 \%$, 78/79). Notably, BLV prevalence increased with age in cattle; BLV proviral DNA was detected in $57.8 \%(93 / 161)$ and $11.4 \%(9 / 79)$ of cattle in the $>15.5$ months and $\leq 15.5$ months groups, respectively $(p<0.001)$. In contrast, the BLV prevalence was generally equal for these two age groups of beef cattle (i.e., $12.2 \%, 16 / 131 ; 10.9 \%, 7 / 64$, respectively, $p=0.795$ ). Moreover, in dairy cows older than 15.5 months, BLV infection was significantly associated with the factors of having been bred with both artificial insemination and bulls $(p<0.001)$, receiving rectal palpation $(p<0.001)$, and not having a vaccination history $(p<0.001)$.

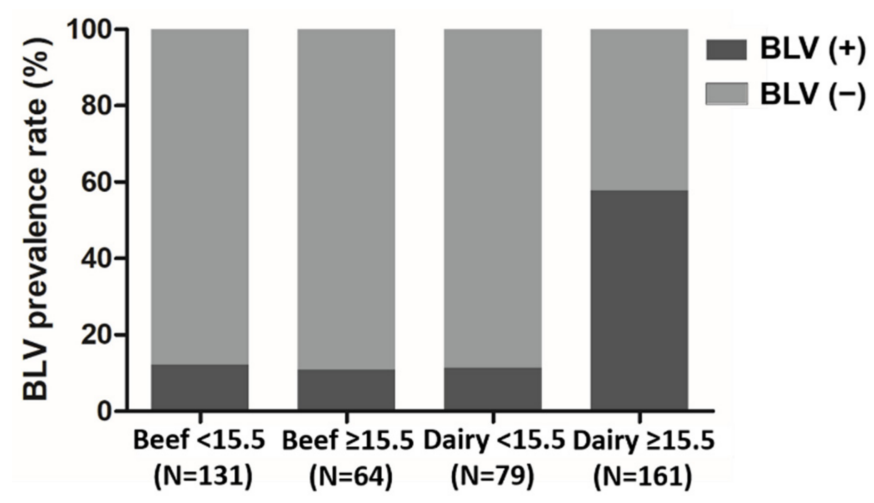

Figure 2. Prevalence of BLV in beef and dairy cows, divided by age. The cut-off value of age (15.5 months) was determined by ROC curve analysis. The status of BLV proviral DNA of each age group in beef and dairy cows is shown individually. 
Table 2. Univariate analysis of the association of farm characteristics with BLV infection of beef and dairy cows.

\begin{tabular}{|c|c|c|c|c|c|c|}
\hline \multirow{2}{*}{ Factors } & \multicolumn{3}{|c|}{ BLV in Beef Cattle } & \multicolumn{3}{|c|}{ BLV in Dairy Cows } \\
\hline & Positive $(n=23)$ & Negative $(n=172)$ & $p$-Value & Positive $(n=102)$ & Negative $(n=138)$ & $p$-Value \\
\hline Age (months) & $17.07 \pm 3.49^{+}$ & $19.08 \pm 1.41^{\dagger}$ & $0.871 \ddagger$ & $38.28 \pm 1.99^{\dagger}$ & $23.20 \pm 1.80^{+}$ & $<0.001 \ddagger$ \\
\hline $\begin{array}{l}\text { Breed } \\
\text { Holstein } \\
\text { Angus } \\
\text { Mixed }\end{array}$ & $\begin{array}{l}16 \\
6 \\
1\end{array}$ & $\begin{array}{c}111 \\
55 \\
6\end{array}$ & $0.841^{\S}$ & $\begin{array}{c}102 \\
0 \\
0\end{array}$ & $\begin{array}{c}138 \\
0 \\
0\end{array}$ & NA \\
\hline $\begin{array}{c}\text { Gender } \\
\text { Male } \\
\text { Female } \\
\text { Castrated Male }\end{array}$ & $\begin{array}{l}13 \\
7 \\
3\end{array}$ & $\begin{array}{l}97 \\
61 \\
14\end{array}$ & $0.702 \S$ & $\begin{array}{c}0 \\
102 \\
0\end{array}$ & $\begin{array}{c}0 \\
138 \\
0\end{array}$ & NA \\
\hline $\begin{array}{c}\text { Herd size } \\
\quad<50 \\
50-200 \\
201-400 \\
>400\end{array}$ & $\begin{array}{c}4 \\
2 \\
3 \\
14 \\
\end{array}$ & $\begin{array}{l}13 \\
35 \\
27 \\
97\end{array}$ & $0.276^{\S}$ & $\begin{array}{c}0 \\
17 \\
2 \\
83\end{array}$ & $\begin{array}{c}0 \\
12 \\
18 \\
108\end{array}$ & $0.003 \S$ \\
\hline $\begin{array}{l}\text { Management pattern } \\
\text { Intensive } \\
\text { Pasture }\end{array}$ & $\begin{array}{c}21 \\
2\end{array}$ & $\begin{array}{c}143 \\
29\end{array}$ & $0.542^{\mathbb{I}}$ & $\begin{array}{c}102 \\
0\end{array}$ & $\begin{array}{c}138 \\
0\end{array}$ & NA \\
\hline $\begin{array}{c}\text { Farm owner } \\
1 \\
2 \\
3 \\
4 \\
5 \\
6\end{array}$ & $\begin{array}{c}4 \\
2 \\
3 \\
10 \\
4 \\
0 \\
\end{array}$ & $\begin{array}{c}13 \\
29 \\
27 \\
77 \\
26 \\
0\end{array}$ & $0.514^{\S}$ & $\begin{array}{l}0 \\
0 \\
31 \\
17 \\
14 \\
40\end{array}$ & $\begin{array}{l}0 \\
0 \\
43 \\
12 \\
16 \\
67\end{array}$ & $0.216^{\S}$ \\
\hline $\begin{array}{c}\text { Artificial insemination } \\
\text { No } \\
\text { No (Bull only) } \\
\text { Yes } \\
\text { Yes (Combined) }\end{array}$ & $\begin{array}{l}17 \\
6 \\
0 \\
0\end{array}$ & $\begin{array}{c}111 \\
55 \\
6 \\
0\end{array}$ & $0.522 \S$ & $\begin{array}{l}3 \\
22 \\
63 \\
14\end{array}$ & $\begin{array}{l}28 \\
3 \\
94 \\
13\end{array}$ & $<0.001^{\S}$ \\
\hline $\begin{array}{c}\text { Regular rectal palpation } \\
\text { No } \\
\text { Yes }\end{array}$ & $\begin{array}{c}21 \\
2\end{array}$ & $\begin{array}{l}137 \\
35\end{array}$ & 0.260 II & $\begin{array}{c}8 \\
94\end{array}$ & $\begin{array}{l}59 \\
79\end{array}$ & $<0.001^{\S}$ \\
\hline $\begin{array}{c}\text { Sterilized colostrum } \\
\text { No } \\
\text { Yes }\end{array}$ & $\begin{array}{c}6 \\
17\end{array}$ & $\begin{array}{c}42 \\
130\end{array}$ & $0.862 \S$ & $\begin{array}{c}0 \\
102\end{array}$ & $\begin{array}{c}0 \\
138\end{array}$ & NA \\
\hline $\begin{array}{c}\text { Vaccination } \\
\text { No } \\
\text { Yes (Needle sharing) } \\
\text { Yes (One shot per needle) }\end{array}$ & $\begin{array}{c}3 \\
18 \\
2\end{array}$ & $\begin{array}{l}27 \\
116 \\
29\end{array}$ & $0.525^{\S}$ & $\begin{array}{l}14 \\
48 \\
40\end{array}$ & $\begin{array}{l}16 \\
55 \\
67\end{array}$ & $0.355^{\S}$ \\
\hline
\end{tabular}

${ }^{\dagger}$ The values represented means \pm SEM. Differences of analytes within groups and BLV positivity was performed with the ${ }^{\ddagger}$ Mann-Whitney

$\mathrm{U}$ test, ${ }^{\text {II }}$ Fisher's exact test, and ${ }^{\S}$ Chi-square test. BLV, bovine leukaemia virus. NA, not applicable. $p<0.05$ indicates significant difference.

\subsection{Differences of BLV Expression among the Farm Features of Lactating Dairy Cows and Heifers}

BLV activation may be induced when dairy cows encounter internal stressor stimuli, such as the lactation cycle [20], and herd management of lactating cows is distinct from that of heifers and might be involved in the variable susceptibility to BLV infection. Thus, the dairy cows were further classified into groups of lactating dairy cows and heifers (Table 4). Results indicated that the BLV infection rate was significantly higher in lactating dairy cows that were either bred with bulls $(p=0.004)$ or were from farm $3(p=0.038)$ (Table 4). Notably, age was the only farm factor correlated with BLV infection in heifers. As very limited factors were involved in the BLV infection, multivariate analysis was not further conducted.

\subsection{Prevalence of BLV Env Proviral DNA in the Breeding Bulls, Lactating Dairy Cows and Heifers from Farm 3}

It is worth noting that the BLV prevalence in lactating cows originating from farm 3 was significantly higher $(80 \%, 24 / 30)$ than that in other farms $(58.6 \%, 46.7 \%$, and $52.2 \%$ for farms 4,5 , and 6 , respectively, $p=0.038$, C.I. $=0.031-0.040$ ) (Table 4 ). To investigate the possibility of vertical transmission of BLV in the farm, we further collected blood samples from all breeding bulls (12 cattle) and four offspring delivered by the dairy cows that were 
analysed in this study. BLV proviral DNA was detected in $41.7 \%(5 / 12)$ of breeding bulls, whereas none of the offspring were infected by BLV.

Table 3. Differences of characteristics between lactating dairy cows and heifers classified by age.

\begin{tabular}{|c|c|c|c|}
\hline \multirow[b]{2}{*}{ Factors } & \multicolumn{3}{|c|}{ Age (months) } \\
\hline & $\leq 15.5(n=79)$ & $>15.5(n=161)$ & $p$-Value \\
\hline $\begin{array}{l}\text { Type } \\
\text { Lactating } \\
\text { Heifer }\end{array}$ & $\begin{array}{c}1 \\
78 \\
\end{array}$ & $\begin{array}{c}155 \\
6\end{array}$ & $<0.001$ II \\
\hline $\begin{array}{l}\text { BLV } \\
\text { Negative } \\
\text { Positive }\end{array}$ & $\begin{array}{c}70 \\
9\end{array}$ & $\begin{array}{l}68 \\
93\end{array}$ & $<0.001 \S$ \\
\hline $\begin{array}{l}\text { Herd size } \\
50-200 \\
201-400 \\
>400\end{array}$ & $\begin{array}{c}0 \\
20 \\
59\end{array}$ & $\begin{array}{c}29 \\
0 \\
132\end{array}$ & $<0.001 \S$ \\
\hline $\begin{array}{c}\text { Farm owner } \\
3 \\
4 \\
5 \\
6 \\
\end{array}$ & $\begin{array}{c}39 \\
0 \\
0 \\
40\end{array}$ & $\begin{array}{c}35 \\
29 \\
30 \\
107 \\
\end{array}$ & $<0.001 \S$ \\
\hline $\begin{array}{c}\text { Artificial insemination } \\
\text { No } \\
\text { No (Bull only) } \\
\text { Yes } \\
\text { Yes (Combined) }\end{array}$ & $\begin{array}{c}31 \\
0 \\
47 \\
1\end{array}$ & $\begin{array}{c}0 \\
25 \\
110 \\
26\end{array}$ & $<0.001 \S$ \\
\hline $\begin{array}{c}\text { Regular rectal palpation } \\
\text { No } \\
\text { Yes }\end{array}$ & $\begin{array}{l}67 \\
12\end{array}$ & $\begin{array}{c}0 \\
161\end{array}$ & $<0.001 \S$ \\
\hline $\begin{array}{c}\text { Vaccination } \\
\text { No } \\
\text { Yes (Needle sharing) } \\
\text { Yes (One shot per needle) }\end{array}$ & $\begin{array}{c}0 \\
39 \\
40\end{array}$ & $\begin{array}{l}30 \\
64 \\
67\end{array}$ & $<0.001 \S$ \\
\hline
\end{tabular}

Differences of analytes within groups and BLV positivity was performed with ${ }^{\mathbb{I}}$ Fisher's exact test and a $\S$ Chi-square test. BLV, bovine leukaemia virus. $p<0.05$ indicates significant difference.

Table 4. Univariate analysis of farm characteristics and BLV infection of lactating dairy cows and heifers.

\begin{tabular}{|c|c|c|c|c|c|c|}
\hline \multirow{2}{*}{ Factors } & \multicolumn{3}{|c|}{ BLV in Lactating Dairy Cows } & \multicolumn{3}{|c|}{ BLV in Heifers } \\
\hline & Positive $(n=90)$ & Negative $(n=66)$ & $p$-Value & Positive $(n=12)$ & Negative $(n=72)$ & $p$-Value \\
\hline Age (months) & $41.94 \pm 1.94^{\dagger}$ & $39.98 \pm 2.36^{\dagger}$ & $0.336 \ddagger$ & $10.83 \pm 1.41^{\dagger}$ & $7.81 \pm 0.51^{\dagger}$ & $0.049 \ddagger$ \\
\hline $\begin{array}{l}\text { Herd size } \\
50-200 \\
>400\end{array}$ & $\begin{array}{l}17 \\
73\end{array}$ & $\begin{array}{l}12 \\
54\end{array}$ & $0.911^{\S}$ & $\begin{array}{c}2 \\
10\end{array}$ & $\begin{array}{l}18 \\
54\end{array}$ & 0.722 II \\
\hline $\begin{array}{c}\text { Farm owner } \\
3 \\
4 \\
5 \\
6\end{array}$ & $\begin{array}{l}24 \\
17 \\
14 \\
35\end{array}$ & $\begin{array}{c}6 \\
12 \\
16 \\
32\end{array}$ & $0.038^{\S}$ & $\begin{array}{l}7 \\
0 \\
0 \\
5\end{array}$ & $\begin{array}{c}37 \\
0 \\
0 \\
35\end{array}$ & $0.656^{\S}$ \\
\hline $\begin{array}{c}\text { Artificial insemination } \\
\text { No } \\
\text { No (Bull only) } \\
\text { Yes } \\
\text { Combined }\end{array}$ & $\begin{array}{c}0 \\
22 \\
54 \\
14\end{array}$ & $\begin{array}{c}0 \\
3 \\
50 \\
13\end{array}$ & $0.004 \S$ & $\begin{array}{l}3 \\
0 \\
9 \\
0\end{array}$ & $\begin{array}{c}28 \\
0 \\
44 \\
0\end{array}$ & $0.521^{\mathbb{I I}}$ \\
\hline $\begin{array}{c}\text { Regular rectal palpation } \\
\text { No } \\
\text { Yes }\end{array}$ & $\begin{array}{c}0 \\
90\end{array}$ & $\begin{array}{c}0 \\
66\end{array}$ & NA & $\begin{array}{l}8 \\
4\end{array}$ & $\begin{array}{l}59 \\
13\end{array}$ & $0.251^{\mathbb{I}}$ \\
\hline $\begin{array}{c}\text { Vaccination } \\
\text { No } \\
\text { Yes (Needle sharing) } \\
\text { Yes (One shot per needle) }\end{array}$ & $\begin{array}{l}14 \\
41 \\
35\end{array}$ & $\begin{array}{l}16 \\
18 \\
32\end{array}$ & $0.059 \S$ & $\begin{array}{l}0 \\
7 \\
5\end{array}$ & $\begin{array}{c}0 \\
37 \\
35\end{array}$ & $0.656^{\S}$ \\
\hline
\end{tabular}

$\dagger$ The values represented means \pm SEM. Differences of analytes within groups and BLV positivity was performed with $\ddagger$ Mann-Whitney U test, ${ }^{\mathbb{I}}$ Fisher's exact test, and ${ }^{\S}$ Chi-square test. BLV, bovine leukaemia virus. NA, not applicable. $p<0.05$ indicates significant difference. 
Moreover, to investigate the prevalence of BLV in milk, both milk and blood samples were randomly collected from 31 lactating dairy cows on farm 3, and BLV proviral DNA was simultaneously detected. The prevalence of BLV env proviral DNA was $90.3 \%(28 / 31)$ in blood samples and $29.0 \%(9 / 31)$ in milk samples, respectively. It was further found that the testing results of BLV proviral DNA positivity between milk samples and blood samples were not statistically consistent (McNemar's test, $p<0.05)$.

\section{Discussion}

Due to the high prevalence of BLV in dairy cows in Taiwan, it is urgent to identify the primary route of BLV transmission within herds, which could facilitate the formulation of management strategies to control the spread of BLV. Although risk factors for BLV infection have been well documented, the studies were from various regions and continents worldwide. Considering that herd management and medical practices can vary among countries, this study determined the prevalence of BLV proviral DNA in beef cattle and evaluated the risk factors associated with BLV infection between beef and dairy cows in Taiwan for the first time. The prevalence of BLV infection in beef cattle was $11.8 \%(23 / 195)$, which is significantly lower than that of dairy cows $(42.5 \%, p<0.001)$. Although all dairy cows were female, the sex of the cattle was not associated with BLV prevalence in beef. Specifically, in the case of female beef $(n=68)$, the BLV prevalence was as low as $10.2 \%(7 / 68)$, which is similar to the overall prevalence $(11.8 \%)$ in the beef group. Nevertheless, our results strongly indicated that dairy cows are significantly more susceptible to BLV infection than female beef (Supplementary Table S1). Noticeably, the BLV infection rate in dairy cows varied among the herds analysed in this study. Dairy cows with older ages had a higher BLV prevalence, and a higher BLV prevalence in lactating dairy cows was positively associated to cattle receiving bull breeding $(p<0.001)$, heifers at older ages $(p<0.001)$, and routine rectal palpations $(p<0.001)$ (Table 3$)$. In contrast, none of the parameters analysed herein were associated with BLV prevalence in beef cattle.

The prevalence of BLV proviral DNA in the present study was considerably lower in beef cattle than in dairy cows, which was consistent with other reports originating from other countries, such as Japan [21] and the United States [5]. Certain differences were indicated between these two sectors. First, the overall health plan (e.g., vaccination programs) and herd management practices (e.g., frequency of pregnancy examination) differed for dairy versus beef cattle. In addition, the immune response and susceptibility to pathogens of dairy cows might differ from those of beef cattle and may be attributed to inherent variability [22]. According to these intrinsic differences and distinct herd management practices between dairy and beef cattle, and even between herds with the same production purpose, the two sectors might not be exposed to the same risk factors at an equivalent frequency. Noticeably, although no parameters associated with BLV prevalence were identified in beef cattle, based on the stratification analysis (Table 2), the presence of BLV proviral DNA in dairy cows was positively associated with age, herd size, breeding method, and rectal palpation (Table 2).

It has been demonstrated that the prevalence of BLV gradually increased with age in dairy cows, and the odds ratio for BLV infection in dairy cows $\geq 6$ years old was increased 2.3-fold, compared with that noted for dairy cows $\leq 1$ year old [19]. Similarly, Gutiérrez et al. monitored BLV progression from birth until the first lactation in a farm where management procedures for the prevention of blood contact were fully implemented. The results indicated that BLV infection was undetectable in cattle from birth to 12 months, whereas proviral DNA was detected from 15 months of age and increased with age [15]. In our study, as indicated in Figure 2, the prevalence of BLV in cattle under the age of 15.5 months did not differ between beef $(11.8 \%, 15 / 127)$ and dairy cows $(11.3 \%, 8 / 71)$, whereas the overall BLV prevalence in dairy cows $(42.5 \%)$ was much higher than that in beef cattle $(11.8 \%)$. Notably, the mean age of beef cattle $(18.62 \pm 18.41$ vs. $29.61 \pm 21.94, p<0.001)$ was much younger than that of dairy cows; hence, it is possible that the age of animals enrolled in this study biased the BLV prevalence in these two sectors. 
Indeed, based on the cut-off value (i.e., 15.5 months) determined by the ROC analysis, BLV prevalence in two age groups was further assessed. The prevalence of BLV proviral DNA was $11.4 \%$ and $57.8 \%$ in the dairy cows at ages younger and older than 15.5 months, respectively (Figure 2), indicating that the risk of BLV infection increased significantly with age in dairy cows $(p<0.001)$. The cows were accommodated in free-stall housing, and given that horizontal transmission via direct contact or indirect exposure (e.g., iatrogenic procedures) of susceptible animals to the infected blood is reported as the major route of BLV spread [12], one can expect the chance of BLV contact and the level of BLV viral load in cattle to increase over time, thus ultimately increasing the risk of infection. Moreover, several lines of evidence indicated blood-sucking insects, such as stable flies and horn flies, as a risk factor of BLV transmission under experimental conditions [23,24]. Hence, an increase of the frequency of exposure to mechanical transmission vectors could also contribute to the higher BLV prevalence in older cows.

Based on body size, most dairy heifers reach puberty when cattle undergo regular breeding procedures at the age of approximately 15 months [15]. Thereafter, the dairy cows were further divided into heifer and lactating dairy cows to adjust for the possible impact of age on BLV infection. As indicated in Table 4, age was the only risk factor for BLV infection in dairy heifers following subgrouping. Notably, BLV positivity was detected only in $11.5 \%$ of heifers $(9 / 78)<15.5$ months old, which was significantly lower than that noted in those $>15.5$ months old $(50 \%, 3 / 6)$. Noticeably, all heifers older than 15.5 months $(\mathrm{N}=6)$ originated from farm 3 , and three out of the six heifers with BLV positivity were bred using artificial insemination and rectal palpation. Single-use rectal gloves during pregnancy examination could possibly avoid virus spreading carried over from the infected cows previously examined, given that the number of palpations conducted with the same gloves was positively correlated with BLV positivity [12]. Moreover, older heifers (ranging 17-21 months old) and breeding with bulls might reflect that breeding management was not well controlled on farm 3 . These factors could all contribute to the remarkably higher BLV prevalence in dairy cows on farm 3.

In addition, an apparently higher BLV prevalence was noticed in lactating dairy cows that were bred with bulls $(88 \%, 22 / 25)$. BLV transmission occurs mainly through the transfer of BLV-containing lymphocytes present primarily in blood, colostrum, and milk [25], and potentially in other biological fluids, such as the semen of BLV-infected bulls [26]. The role of breeding bulls in BLV transmission has been reported [27]. Natural services may facilitate BLV dissemination via trauma during copulation, resulting in the transfer of blood between infected and uninfected animals. As evidenced by the presence of BLV proviral DNA, in addition to blood, semen, or smegma, could also mediate BLV dissemination to recipient cows [27]. However, very recently, a report from Benitez et al. demonstrated that the natural breeding of cattle does not represent a route for BLV transmission, based on studies monitoring the BLV infection status of heifers co-housed with BLV-affected bulls [28]. Given that the study was performed over a 38-day co-housing period during a defined breeding season, the contact frequency and the BLV proviral load of bulls should be also taken into account when evaluating the possible contribution of natural breeding with bulls to BLV transmission in cows. In the current study, bulls from farm 3 were purchased from another farm, and BLV proviral DNA was detected in five out of twelve bulls $(41.7 \%)$. Considering that the exposure of susceptible animals to infected blood is one of the major methods for the spread of BLV [12], confirmation of the BLV-free status of new cattle (e.g., bulls or calves) purchased from other farms, and of herd bulls prior to the breeding season, could be beneficial for mitigating the spread of the virus within the herd.

In this study, BLV prevalence in beef cattle was depicted, and for risk assessment, BLV proviral DNA in dairy cows was simultaneously detected. However, as described herein, BLV prevalence in dairy cows is relatively lower than that reported in one previous study [18]. Notably, the experiment design differed in these two studies. In the current study, to determine the relation of age with BLV prevalence, we purposely collected cattle at different age groups, including 84 young heifers, for which BLV prevalence $(11.4 \%)$ was 
significantly lower than cows in the older age group. However, in the previous study, six cattle were randomly selected from one herd. Since the previous study was unable to track the ages of cattle, we cannot measure the contribution of the sampling difference to the variation of BLV prevalence in the two studies. Moreover, the high prevalence of BLV in Taiwan has been noted since the first nationwide BLV surveillance, conducted in 2016 [18]. Hence, we suspected, in addition to the aforementioned sampling bias, that the lower BLV prevalence could be possibly due to the effectiveness of prevention propaganda, such as the use of single-use rectal gloves for palpation, using one needle per cow for vaccination, etc.

\section{Materials and Methods}

\subsection{Sample Collection}

A cross-sectional study was carried out on cattle in four major counties with beef farming in Taiwan in 2019. The minimal sampling number of cattle and herd for prevalence estimation were determined based on the assumptions of $95 \%$ confidence, $5 \%$ error rate of the prevalence, and BLV seroprevalence of $81.8 \%$ and $99.1 \%$ at the animal and herd levels, respectively, according to the previous study in Taiwan [18].

There are two sets of experiments: (I) initially, for the evaluation of BLV proviral DNA prevalence, a total of 435 whole blood samples were drawn in EDTA tubes from 195 beef cattle and 240 dairy cows composed of lactating dairy cows $(n=156)$ and heifers $(n=84)$ of six herds in central and southern Taiwan (Figure 3, and Table 5). (II) For the evaluation of the possibility of vertical transmission, as well as the detection of the BLV in milk, 16 whole blood samples were obtained from 12 breeding bulls and 4 offspring delivered by the cows analysed in this study, as well as 31 milk samples collected from 31 lactating dairy cows from farm 3, located in southern Taiwan (Figure 3).

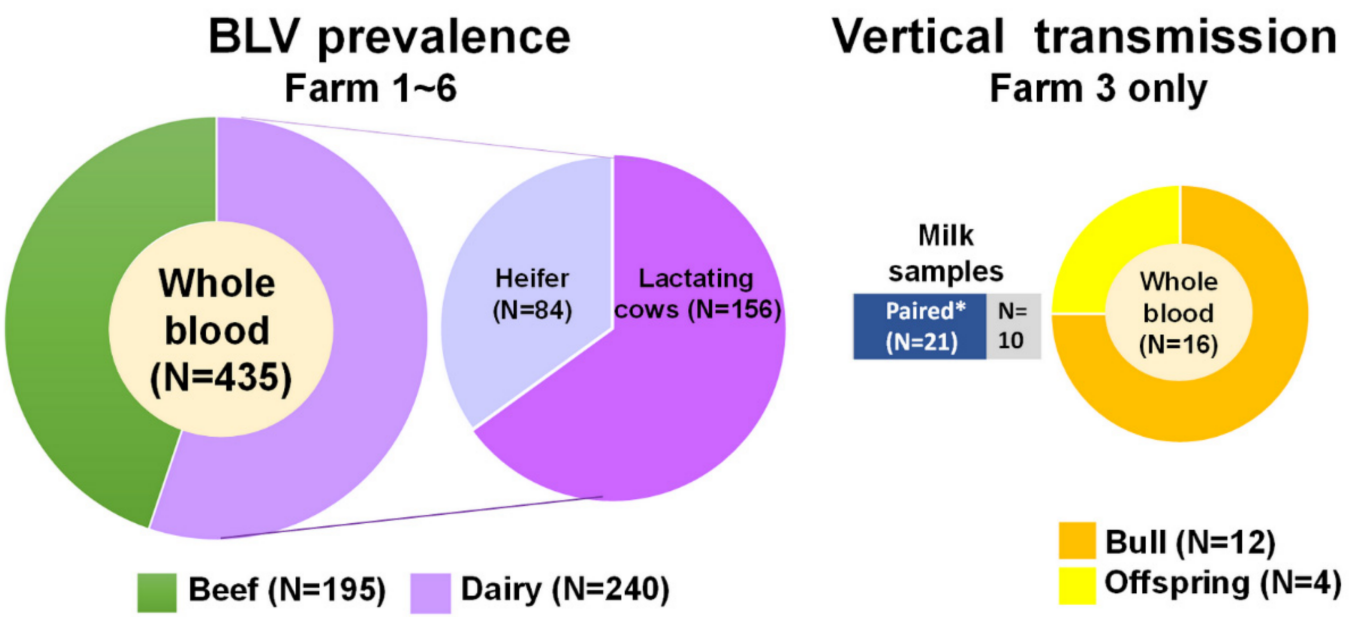

Figure 3. Samples enrolled in this study. For analysis of BLV prevalence, a total of 435 whole blood samples were collected from 195 beef cattle and 240 dairy cows, including lactating dairy cows $(n=156)$ and heifers $(n=84)$, from six herds in central and southern Taiwan. Moreover, for the vertical transmission study, 16 whole blood samples were obtained from 12 breeding bulls and 4 offspring, as well as 31 milk samples collected from 31 lactating dairy cows from farm 3 , located in southern Taiwan. Notably, 21 out of 31 milk samples were collected from the lactating cows enrolled in the horizontal study (i.e., pair sample, indicated as paired ${ }^{*}$ ).

All samples were obtained from healthy cattle without clinical signs of disease that were evaluated by experienced veterinarians, based on the criteria used in a previous study [18], and with the owner's consent. The medical records of each cattle were collected during the farm visit for further statistical analysis. To this end, a questionnaire was designed to collect data on cattle information, including the species, age, breed, and gender of the cattle, and the herd size of the farm, as well as the herd health-management practices, including the methods of artificial insemination, frequency of rectal palpation, colostrum condition, and records of vaccination, etc., as listed in Table 1. 
Table 5. Basic information of the beef and dairy cows analysed in this study.

\begin{tabular}{|c|c|c|c|c|c|c|}
\hline \multirow{2}{*}{ Factors } & \multicolumn{6}{|c|}{ Farm Owner } \\
\hline & $1(n=17)$ & $2(n=31)$ & $3(n=120)$ & $4(n=116)$ & $5(n=60)$ & $6(n=107)$ \\
\hline Production usage & Beef & Beef & Mixed & Mixed & Mixed & Dairy \\
\hline \multicolumn{7}{|l|}{ Types } \\
\hline Beef & 17 & 31 & 30 & 87 & 30 & 0 \\
\hline Dairy & 0 & 0 & 30 & 29 & 30 & 67 \\
\hline Heifer & 0 & 0 & 44 & 0 & 0 & 40 \\
\hline Offspring & 0 & 0 & 4 & 0 & 0 & 0 \\
\hline Breeding bull & 0 & 0 & 12 & 0 & 0 & 0 \\
\hline Age (months) & $10.15 \pm 0.55^{\dagger}$ & $48.00 \pm 0.00^{\dagger}$ & $18.87 \pm 1.55^{\dagger}$ & $13.59 \pm 1.50^{\dagger}$ & $46.80 \pm 2.63^{\dagger}$ & $25.89 \pm 1.83^{\dagger}$ \\
\hline \multicolumn{7}{|l|}{ Breed } \\
\hline Holstein & 16 & 0 & 120 & 110 & 30 & 107 \\
\hline Angus & 0 & 31 & 0 & 0 & 30 & 0 \\
\hline Mixed & 1 & 0 & 0 & 6 & 0 & 0 \\
\hline \multicolumn{7}{|l|}{ Gender } \\
\hline Male & 0 & 0 & 41 & 81 & 0 & 0 \\
\hline Female & 1 & 31 & 74 & 35 & 60 & 107 \\
\hline Castrated male & 16 & 0 & 5 & 0 & 0 & 0 \\
\hline Herd size & $<50$ & 50-200 & $>400$ & 50-200 & $>400$ & $>400$ \\
\hline Management pattern & Intensive & Pasture & Intensive & Intensive & Intensive & Intensive \\
\hline
\end{tabular}

\subsection{DNA Extraction and Detection of BLV Proviral DNA by Nested PCR}

Genomic DNA was extracted from the leukocytes fractionated from $5 \mathrm{~mL}$ of anticoagulated blood samples, and from milk somatic cells isolated from $15 \mathrm{~mL}$ of raw milk, by using the AllPure Genomic DNA Kit (Universal, AllBio, Taichung, Taiwan) according to the manufacturer's instructions. DNA samples were stored at $-20{ }^{\circ} \mathrm{C}$ until polymerase chain reaction (PCR) was conducted. The quantity of DNA was measured by spectrophotometry (NanoDrop Lite, Thermo Scientific, Waltham, MA, USA), and the integrity of DNA was further validated by PCR with a set of primers for the amplification of bovine glyceraldehyde 3-phosphate dehydrogenase (GAPDH), which was used in the previous report [29].

The BLV proviral DNA was detected by nested PCR via the amplification of the partial env gene with two sets of primers, designated as BLV-env-1 5'-TCT GTG CCA AGT CTC CCA GAT A-3' (outer forward) and BLV-env-2 5'-AAC AAC AAC CTC TGG GAA GGG-3' (outer reverse), and BLV-env-3 5'-CCC ACA AGG GCG GCG CCG GTT T-3' (inner forward) and BLV-env-4 5'-GCG AGG CCG GGT CCA GAG CTG G-3' (inner reverse), which were described previously [18]. The PCR conditions of BLV env amplification were set according to a previous study [30]. For the genotyping of BLV, the identity of the env amplicons was confirmed by an automated Sanger's sequencing method (Mission Biotec, Taipei, Taiwan).

\subsection{Statistical Analysis}

The differences in BLV proviral DNA positivity detected from the whole blood samples of various types of cattle (beef cattle, lactating dairy cows, or heifers), and the different features of cattle, such as species, breed, gender, the farm from where those cattle originated, and herd size, as well as management procedures, including artificial insemination, rectal palpation, sterilized colostrum feeding, and vaccination conditions, were comparatively analysed via the Chi-square test. However, owing to the limited study size, the difference in BLV proviral DNA positivity by different farm management patterns was evaluated by Fisher's exact test. In addition, to compare the mean age difference between BLV proviral DNA positive and negative animals, the Mann-Whitney U test was applied because normal distributions were not indicated among these two groups. Those explanatory variables with significant difference $(p<0.05)$ were then selected for the multivariate analysis. Risk 
evaluation for the relationship between age and the presence of BLV proviral DNA was determined by receiver operating characteristic (ROC) curve analysis. The critical age for further stratification analysis was determined by the maximized sum of sensitivity and specificity from the ROC curve. The consistency of BLV proviral DNA positivity between blood samples and milk samples was evaluated by McNemar's test. The statistical analysis was conducted with the Statistical Package for the Social Sciences (SPSS Version 22, Asia Analytics Taiwan, Ltd. Taipei, Taiwan.) All $p$ values were carried out with two-tailed tests, and the statistical significance was determined by $p$ values less than 0.05 .

\section{Conclusions}

To date, eradication programs of BLV have not yet been established nationwide in Taiwan. This study reported, for the first time, the prevalence of BLV infections in beef cattle in Taiwan, and identified several within-herd factors, including age, cattle breeding using bulls, and routine rectal palpation, which are positively associated with BLV infections. BLV is widespread in Taiwan. The limitation of this study was due to the unknown BLV prevalence, and the sampling design for beef cattle was based on dairy cows, which led to a small sample size of beef cattle. Despite the small scale of this investigation, the findings may inform the formulation of preventive measures for reducing the clinical impacts of BLV infection in certain contaminated farms, particularly when a nationwide risk assessment is not available.

Supplementary Materials: The following are available online at https:/ /www.mdpi.com/article/ 10.3390 / pathogens10121553/s1, Table S1. BLV proviral DNA prevalence in female beef cattle and dairy cows.

Author Contributions: Conceptualization, W.-L.H.; project administration, W.-Y.C. and Y.-C.C.; supervision, W.-L.H.; resources, W.-Y.C. and S.-T.C.; validation, C.-C.C. and Y.-C.C.; writing-original draft preparation, W.-L.H. and Y.-C.C.; writing-review and editing, W.-L.H. and Y.-C.C. All authors have read and agreed to the published version of the manuscript.

Funding: This research received no external funding.

Institutional Review Board Statement: Ethical review and approval were waived for this study, since the bovine blood samples were remanent specimens spared by the Veterinary Medicine Teaching Hospital of National Chung Hsing University. Samples were collected by experienced veterinarians during routine farm visits for the regular examination of serum biochemistry, and the use of these specimens for this study was granted by the owners of these private farms.

Informed Consent Statement: Not applicable.

Data Availability Statement: All the data supporting the findings of this study can be found within the article.

Acknowledgments: We are grateful for the help and time of all farmers, veterinarians, and staff involved in the sampling process.

Conflicts of Interest: The authors declare that they have no conflicting or competing financial or personal interests that could inappropriately influence or bias the work reported in this study.

\section{References}

1. Burny, A.; Cleuter, Y.; Kettmann, R.; Mammerickx, M.; Marbaix, G.; Portetelle, D.; van den Broeke, A.; Willems, L.; Thomas, R. Bovine leukaemia: Facts and hypotheses derived from the study of an infectious cancer. Vet. Microbiol. 1988, 17, 197-218. [CrossRef]

2. Nekouei, O.; VanLeeuwen, J.; Stryhn, H.; Kelton, D.; Keefe, G. Lifetime effects of infection with bovine leukemia virus on longevity and milk production of dairy cows. Prev. Vet. Med. 2016, 133, 1-9. [CrossRef] [PubMed]

3. Sargeant, J.M.; Kelton, D.F.; Martin, S.W.; Mann, E.D. Associations between farm management practices, productivity, and bovine leukemia virus infection in Ontario dairy herds. Prev. Vet. Med. 1997, 31, 211-221. [CrossRef]

4. Bartlett, P.C.; Norby, B.; Byrem, T.M.; Parmelee, A.; Ledergerber, J.T.; Erskine, R.J. Bovine leukemia virus and cow longevity in Michigan dairy herds. J. Dairy Sci. 2013, 96, 1591-1597. [CrossRef] [PubMed] 
5. Benitez, O.J.; Norby, B.; Bartlett, P.C.; Maeroff, J.E.; Grooms, D.L. Impact of bovine leukemia virus infection on beef cow longevity. Prev. Vet. Med. 2020, 181, 105055. [CrossRef]

6. Buehring, G.C.; Philpott, S.M.; Choi, K.Y. Humans have antibodies reactive with Bovine leukemia virus. AIDS Res. Hum. Retrovir. 2003, 19, 1105-1113. [CrossRef]

7. Buehring, G.C.; Shen, H.M.; Jensen, H.M.; Choi, K.Y.; Sun, D.; Nuovo, G. Bovine leukemia virus DNA in human breast tissue. Emerg. Infect. Dis. 2014, 20, 772-782. [CrossRef]

8. LaDronka, R.M.; Ainsworth, S.; Wilkins, M.J.; Norby, B.; Byrem, T.M.; Bartlett, P.C. Prevalence of Bovine Leukemia Virus Antibodies in US Dairy Cattle. Vet. Med. Int. 2018, 2018, 5831278. [CrossRef]

9. VanLeeuwen, J.A.; Keefe, G.P.; Tremblay, R.; Power, C.; Wichtel, J.J. Seroprevalence of infection with Mycobacterium avium subspecies paratuberculosis, bovine leukemia virus, and bovine viral diarrhea virus in maritime Canada dairy cattle. Can. Vet. J. 2001, 42, 193-198.

10. Murakami, K.; Kobayashi, S.; Konishi, M.; Kameyama, K.; Yamamoto, T.; Tsutsui, T. The recent prevalence of bovine leukemia virus (BLV) infection among Japanese cattle. Vet. Microbiol. 2011, 148, 84-88. [CrossRef]

11. Yang, Y.; Fan, W.; Mao, Y.; Yang, Z.; Lu, G.; Zhang, R.; Zhang, H.; Szeto, C.; Wang, C. Bovine leukemia virus infection in cattle of China: Association with reduced milk production and increased somatic cell score. J. Dairy Sci. 2016, 99, 3688-3697. [CrossRef]

12. Nekouei, O.; VanLeeuwen, J.; Sanchez, J.; Kelton, D.; Tiwari, A.; Keefe, G. Herd-level risk factors for infection with bovine leukemia virus in Canadian dairy herds. Prev. Vet. Med. 2015, 119, 105-113. [CrossRef]

13. Meas, S.; Usui, T.; Ohashi, K.; Sugimoto, C.; Onuma, M. Vertical transmission of bovine leukemia virus and bovine immunodeficiency virus in dairy cattle herds. Vet. Microbiol. 2002, 84, 275-282. [CrossRef]

14. Gillet, N.A.; Gutierrez, G.; Rodriguez, S.M.; de Brogniez, A.; Renotte, N.; Alvarez, I.; Trono, K.; Willems, L. Massive depletion of bovine leukemia virus proviral clones located in genomic transcriptionally active sites during primary infection. PLoS Pathog. 2013, 9, e1003687. [CrossRef]

15. Gutierrez, G.; Alvarez, I.; Politzki, R.; Lomonaco, M.; Dus Santos, M.J.; Rondelli, F.; Fondevila, N.; Trono, K. Natural progression of Bovine Leukemia Virus infection in Argentinean dairy cattle. Vet. Microbiol. 2011, 151, 255-263. [CrossRef] [PubMed]

16. Monti, G.E.; Frankena, K.; De Jong, M.C. Evaluation of natural transmission of bovine leukaemia virus within dairy herds of Argentina. Epidemiol. Infect. 2007, 135, 228-237. [CrossRef]

17. Kobayashi, S.; Tsutsui, T.; Yamamoto, T.; Hayama, Y.; Kameyama, K.; Konishi, M.; Murakami, K. Risk factors associated with within-herd transmission of bovine leukemia virus on dairy farms in Japan. BMC Vet. Res. 2010, 6, 1. [CrossRef]

18. Hsieh, J.C.; Li, C.Y.; Hsu, W.L.; Chuang, S.T. Molecular Epidemiological and Serological Studies of Bovine Leukemia Virus in Taiwan Dairy Cattle. Front. Vet. Sci. 2019, 6, 427. [CrossRef]

19. Sun, W.W.; Lv, W.F.; Cong, W.; Meng, Q.F.; Wang, C.F.; Shan, X.F.; Qian, A.D. Mycobacterium avium Subspecies paratuberculosis and Bovine Leukemia Virus Seroprevalence and Associated Risk Factors in Commercial Dairy and Beef Cattle in Northern and Northeastern China. Biomed. Res. Int. 2015, 2015, 315173. [CrossRef] [PubMed]

20. Jaworski, J.P.; Petersen, M.I.; Carignano, H.A.; Trono, K.G. Spontaneous virus reactivation in cattle chronically infected with bovine leukemia virus. BMC Vet. Res. 2019, 15, 150. [CrossRef] [PubMed]

21. Kobayashi, S.; Hidano, A.; Tsutsui, T.; Yamamoto, T.; Hayama, Y.; Nishida, T.; Muroga, N.; Konishi, M.; Kameyama, K.; Murakami, $\mathrm{K}$. Analysis of risk factors associated with bovine leukemia virus seropositivity within dairy and beef breeding farms in Japan: A nationwide survey. Res. Vet. Sci. 2014, 96, 47-53. [CrossRef]

22. Perez O’Brien, A.M.; Utsunomiya, Y.T.; Meszaros, G.; Bickhart, D.M.; Liu, G.E.; Van Tassell, C.P.; Sonstegard, T.S.; Da Silva, M.V.; Garcia, J.F.; Solkner, J. Assessing signatures of selection through variation in linkage disequilibrium between taurine and indicine cattle. Genet. Sel. Evol. 2014, 46, 19. [CrossRef]

23. Panei, C.J.; Larsen, A.E.; Fuentealba, N.A.; Metz, G.E.; Echeverría, M.G.; Galosi, C.M.; Valera, A.R. Study of horn flies as vectors of bovine leukemia virus. Open Vet. J. 2019, 9, 33-37. [CrossRef]

24. Foil, L.D.; Seger, C.L.; French, D.D.; Issel, C.J.; McManus, J.M.; Ohrberg, C.L.; Ramsey, R.T. Mechanical transmission of bovine leukemia virus by horse flies (Diptera: Tabanidae). J. Med. Entomol. 1988, 25, 374-376. [CrossRef]

25. Hopkins, S.G.; DiGiacomo, R.F. Natural transmission of bovine leukemia virus in dairy and beef cattle. Vet. Clin. N. Am. Food Anim. Pract. 1997, 13, 107-128. [CrossRef]

26. Ruiz, V.; Porta, N.G.; Lomonaco, M.; Trono, K.; Alvarez, I. Bovine Leukemia Virus Infection in Neonatal Calves. Risk Factors and Control Measures. Front. Vet. Sci. 2018, 5, 267. [CrossRef] [PubMed]

27. Benitez, O.J.; Roberts, J.N.; Norby, B.; Bartlett, P.C.; Takeshima, S.N.; Watanuki, S.; Aida, Y.; Grooms, D.L. Breeding bulls as a potential source of bovine leukemia virus transmission in beef herds. J. Am. Vet. Med. Assoc. 2019, 254, 1335-1340. [CrossRef] [PubMed]

28. Benitez, O.J.; Roberts, J.N.; Norby, B.; Bartlett, P.C.; Maeroff, J.E.; Grooms, D.L. Lack of Bovine leukemia virus transmission during natural breeding of cattle. Theriogenology 2019, 126, 187-190. [CrossRef]

29. Chen, Y.C.; Chang, C.C.; Hsu, W.L.; Chuang, S.T. Dairy cattle with bovine leukaemia virus RNA show significantly increased leukocyte counts. Vet. J. 2020, 257, 105449. [CrossRef] [PubMed]

30. Fechner, H.; Kurg, A.; Geue, L.; Blankenstein, P.; Mewes, G.; Ebner, D.; Beier, D. Evaluation of polymerase chain reaction (PCR) application in diagnosis of bovine leukaemia virus (BLV) infection in naturally infected cattle. Zent. Vet. B 1996, 43, 621-630. [CrossRef] 